\title{
Possibilities for using solar energy to fulfil the energy needs of buildings in the city centre
}

\author{
Adam Bujarkiewicz ${ }^{1, *}$ and Jacek Sztubecki ${ }^{1}$ \\ ${ }^{1}$ UTP University of Science and Technology, Faculty of Civil and Environmental Engineering and \\ Architecture, Al. Prof. S. Kaliskiego 7, 85-796 Bydgoszcz, Poland
}

\begin{abstract}
Historical buildings in the centre of European cities are characterized by compact built-up areas with diversified heights of buildings, most often with multi-sloped roofs. Architectural elements, dormers, chimneys and bay windows, cause limitations in the availability of surface area for solar installations. The paper presents the results of an analysis for possibilities in meeting energy requirements with the use of solar energy for old-town buildings in the centre of Bydgoszcz. Based on the calculations made, it was determined that the dense downtown development has a very large roof surface, however, the vicinity of buildings, roof slope angles, and obstacles cause significant restrictions on the location of such installations. The article analyzes selected fragments of the Downtown district. The height of buildings, their shape and the surface of their roofs and all the obstacles that occur there were taken into account. The conclusions concern an assessment of the possibility of using the potential of solar energy in this type of building. The efficiency of solar installations and the losses associated with energy conversion and transmission to customers is also included.
\end{abstract}

\section{Introduction}

Climate change in the world requires taking action to reduce $\mathrm{CO}_{2}$ emissions. Many countries in the world achieve this goal by improving the energy efficiency of the economy and replacing conventional fuels with modern technologies that use the natural energy resources of the Earth and the Sun $[1,2]$.

A significant amount of energy is consumed in cities. In cities there are also very onerous phenomena resulting from excessive environmental pollution, such as smog and pollination. The main drivers of these phenomena are transport pollution and households, using solid fuels for space heating. Therefore, the use of devices using renewable energy becomes a necessity. The dissemination of renewable energy applications also influences technological development resulting in the reduction of costs and efficiency of devices for the production of "green" energy. In addition, the growing environmental awareness of society and an increase in the prices of conventional energy carriers induce to choose alternative solutions that are environmentally friendly and guarantee the reduction of maintenance costs.

\footnotetext{
*Corresponding author: adamb@utp.edu.pl
} 
Modern technologies offer the possibility of generating energy in the place of their use. In housing construction, the least invasive way of obtaining energy is the installation of photovoltaic cells and solar collectors using solar radiation energy on the roofs of buildings. The use of photovoltaic cells is possible not only for newly designed buildings, but also for existing, often historical buildings [3].

Local governments create many incentives for the use of RES in cities [4]. They publish, for example, maps of solar potential showing the possibilities of solar energy acquisition on the roofs of buildings. Also, EU institutions have prepared special tools [5], which allow estimating the amount of energy possible to be produced by FV modules. There were also many scientific studies that characterize the possibilities of obtaining energy in various cities in different parts of the world [6-9].

However, due to the specific character of the historical development of city centres, depending on the cultural period, locally applied architectural solutions and cultural conditions, cities in different parts of the world show significant diversity regarding the possibility of installing FV modules and acquiring solar energy [10].

The article examines the possibilities of obtaining solar energy on the roofs of buildings in three parts of the centre of Bydgoszcz in Poland and presents the results of the analysis of meeting the energy needs of their residents.

\section{Possibilities of obtaining energy in cities in Poland}

Due to limited space in cities, the most frequently used Renewable Energy Source is solar energy, whereas the systems required to collect energy from the said sources are installed on building roofs or - in very few cases - on building facades.

The principles of solar radiation energy use and conditions in Poland are regulated by the Act of 20 February 2015 on Renewable Energy Sources (Journal of Laws of 2015, item $478,2365)$. It defines the principles and conditions for the generation of electric power from renewable energy sources, as well as the mechanisms and instruments supporting its production.

Considering geographical location, sunlight exposure conditions in Poland are considered good. The vast majority of the country is characterised by sunlight exposure of more than $1000 \mathrm{kWh} / \mathrm{m}^{2}$ per year [11]. These are mainly coastal areas - up to $1137 \mathrm{kWh} / \mathrm{m}^{2}$ and southern areas $\left(1053 \mathrm{kWh} / \mathrm{m}^{2}\right)$. The values for Central Poland are approx. 1022 $\mathrm{kWh} / \mathrm{m}^{2}$.

Despite such high sunlight exposure values, the power of installed photovoltaic systems in Poland in 2016 was only 91.82 MW. In comparison to the overall power of Renewable Energy Source systems in Poland [12], it makes up only 1\%. However, it should be emphasised that in the last three years there was a rapid growth of sunlight energy generation systems (Fig. 1). It can be expected that the system of state support for this type of investment and the increase in efficiency of photovoltaic cells combined with a reduction of their prices will support further intensive use of this energy source.

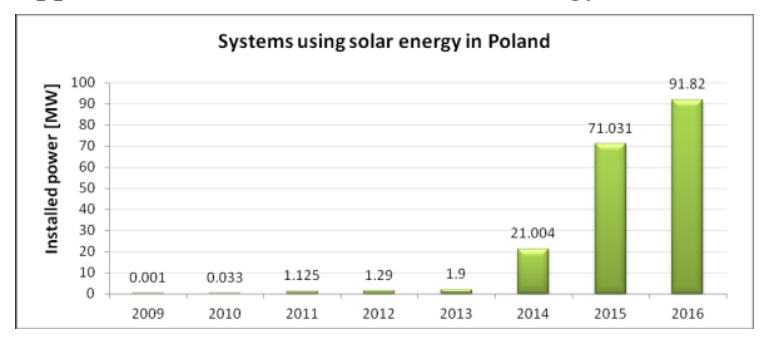

Fig. 1. Power of systems using solar energy in Poland in the years 2009-2016. On the basis of [12]. 
In cities, depending on the location, there is a very diversified density and character of the housing development. The results of analyses carried out by the authors [6] have shown a significant variation in the possibilities of obtaining solar energy in various parts of the city - on a single-family housing estate, in a multi-family housing estate of four and fivestorey buildings and in the city centre with dense stone buildings. For the studied areas, the performed analysis [6] has demonstrated that the acquisition of solar energy in municipal conditions strongly depends on the nature and density development. Multi-family housing areas with high buildings, flat roofs and a relatively low density development are most advantageous in that respect. High density (downtown development) areas have a very large surface of roofs for which total solar radiation is almost 2-3 times higher than in other areas, but their average solar potential is approx. $20 \%$ lower than in areas of a lower density development.

The shape of buildings' roofs is crucial for obtaining solar energy in urban areas. According to the analysis [6], the shape of roofs in the historical downtime development area limits the number of buildings on which installation of photovoltaic cells is profitable to $25 \%$. Due to the results of these analyses, research has been undertaken on the extent to which photovoltaic installations will satisfy the energy demand of residential buildings in the city centre, characterized by tenement houses, often those affected by energy poverty [13].

\section{Analysis of solar potential for fragments of the city centre}

City development is strongly diversified and buildings have roofs of various structures and shapes. Furthermore, depending on the construction period and location within a city, the characteristics of the surroundings, which influence the shading of buildings and sunlight scattering, may vary significantly.

The analysis covered three parts of the centre of Bydgoszcz, characterized by a similar type and time of building, but with different floor area ratio (FAR) and development structure.

\subsection{Methods and sources of data}

LiDAR measurement data saved in LAS format files corresponding to 1:1250 scale sheets and covering areas of approx. $0.5 \times 0.6 \mathrm{~km}$ with an area of 30.3 hectares were used for the analysis. The average density of land coverage point clouds for selected areas was 12 points $/ \mathrm{m}^{2}$, whereas the average height error was $0.1 \mathrm{~m}$ (Fig. 2).

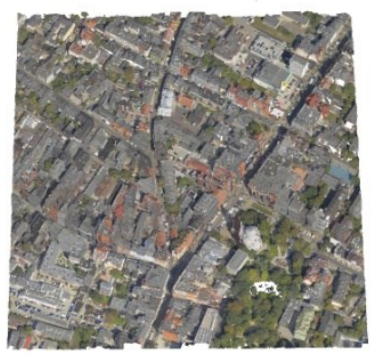

Part C1

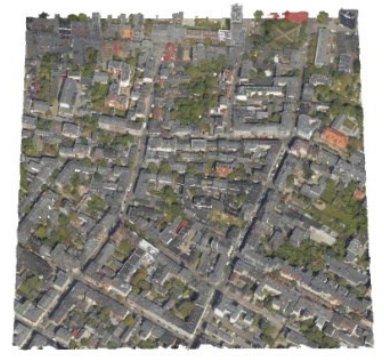

Part C2

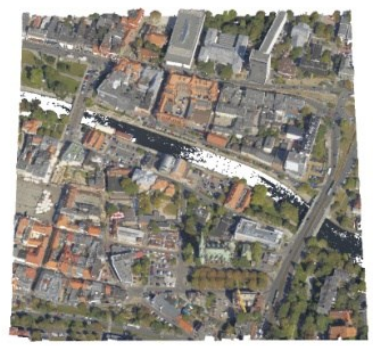

Part C3

Fig. 2. Measurement data presented in the form of RGB colour point clouds for three examined fragments of the city centre in Bydgoszcz. 
Calculations of the solar potential were carried out with standard GIS tools, using the methodology described in many publications [14-18]. When measuring the sunlight exposure, the latitude of a given area was taken into account. Moreover, values of radiation scattering from all sky directions, the average atmospheric diffusion rate of 0.3 and the transmission rate of 0.5 were applied. Measurements in a whole year period with a monthly interval were carried out for each area.

In order to determine the solar potential and global radiation (Fig. 3a), i.e. the sum of direct and scattered radiation was considered.
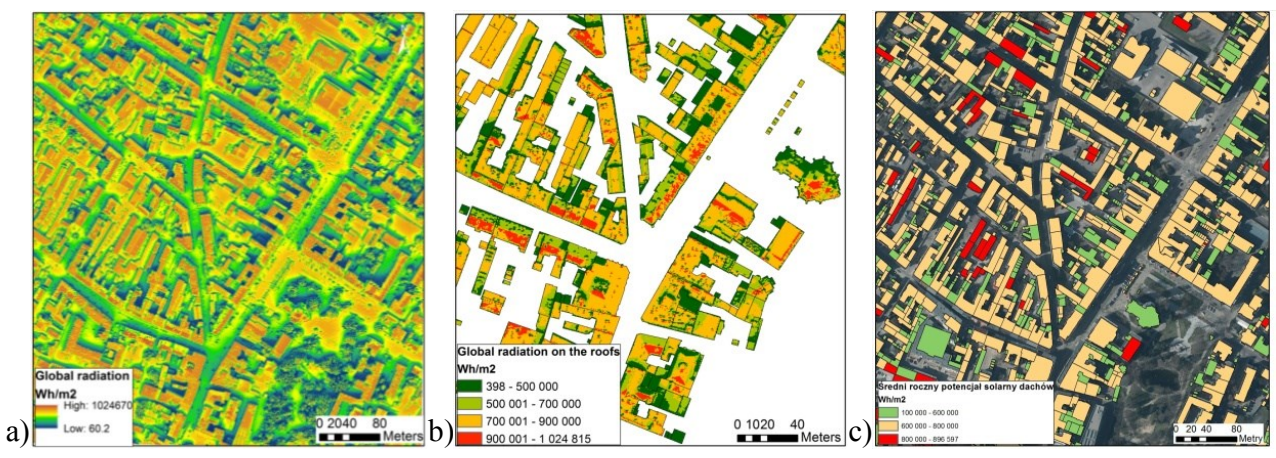

Fig. 3. Results of sunlight exposure measurements for fragment $\mathrm{C} 1$ of the city centre in Bydgoszcz: a) global radiation for the whole area $\left[\mathrm{Wh} / \mathrm{m}^{2}\right]$, b) global radiation on the roofs of the building $\left[\mathrm{Wh} / \mathrm{m}^{2}\right]$, c) the solar potential of roofs $\left[\mathrm{Wh} / \mathrm{m}^{2}\right]$.

In the next stage of the research, due to the nature of the areas, the value of global radiation occurring on the roofs of buildings during the whole year was determined. For this purpose, fragments of the raster in the building outlines were separated and the values for each roof were averaged. The results of such a spatial analysis for part $\mathrm{C} 1$ of the city centre are presented in Figures $3 \mathrm{~b}$ and $3 \mathrm{c}$. The average annual global radiation presented in Fig. 3c is the most commonly used method for characterizing the solar potential of roofs [15].

\subsection{Indicators and assumptions}

Comparative calculations were carried out for three equal areas located in the city centre, characterized by tenement houses. The size of these areas corresponded to the ranges of LiDAR data sheets at a scale of 1:1250. Table 1 shows that the floor area ratio (FAR) and building coverage ratio (BCR) for the area $\mathrm{C} 1$ and $\mathrm{C} 2$ are similar, while in the area of $\mathrm{C} 3$ these rates are lower. This is due to a river flowing through and numerous green areas. Consequently, in the area of $\mathrm{C} 3$, the total roof surface is almost twice smaller than in other areas.

Assuming that solar panels are installed always parallel to the roof slope, for each area, the total annual values of radiation reaching the roof surfaces were calculated. The results of these calculations are given in Table 1 .

Table 1. Characteristics of the analyzed areas.

\begin{tabular}{|l|c|c|c|}
\hline \multicolumn{1}{|c|}{ Factor } & Part C1 & Part C2 & Part C3 \\
\hline Building Coverage Ratio (BCR) & $38 \%$ & $34 \%$ & $23 \%$ \\
\hline Average floor area ratio (FAR) & 0.99 & 0.90 & 0.60 \\
\hline Total roof area $\left[\mathrm{m}^{2}\right]$ & 116127 & 104351 & 68171 \\
\hline Average roof area $\left[\mathrm{m}^{2}\right]$ & 126 & 103 & 137 \\
\hline The sum of radiation for the surface of all roofs $[\mathrm{GWh}]$ & 76.3 & 69.5 & 42.5 \\
\hline Average annual radiation on roofs $\left[\mathrm{kWh} / \mathrm{m}^{2}\right]$ & 563 & 583 & 552 \\
\hline
\end{tabular}


The solar potential set presented in Table 1 confirms the exact dependence of the amount of energy on the active surface. However, calculated per roof, the average annual radiation is at a similar level and it equals from $552 \mathrm{kWh} / \mathrm{m}^{2}$ for the $\mathrm{C} 3$ area, to 583 $\mathrm{kWh} / \mathrm{m}^{2}$ for the $\mathrm{C} 2$ area. It is therefore confirmed that there are similar conditions for acquiring solar energy in various areas of historical downtown development and they can be included in further analyses.

In detailed calculations, it should be taken into consideration that the efficiency of solar modules depends on the size and homogeneity of the solar radiation reaching them, and that on the roofs of historic tenement houses there are often various architectural elements (such as dormers, bay windows or chimneys) limiting the surface accessibility for solar installations. In addition, the investment for one building becomes profitable if the solar panels are installed in places with sufficiently high solar potential.

Bearing in mind the above limitations, further calculations were carried out taking into account only such roof fragments, which average annual potential exceeds $800 \mathrm{kWh} / \mathrm{m}^{2}$ and the surface of which allows for installing solar modules with standard dimensions.

On the basis of calculated global radiation, uniform roof pieces of a solar potential above $800 \mathrm{kWh} / \mathrm{m}^{2}$, a surface equal to or higher than $1.7 \mathrm{~m}^{2}$ and a shape similar to a rectangular with a shorter side of at least $1 \mathrm{~m}$ were determined for each building roof. Fig. 4 presents an example of classification of roof surfaces by their shape, size and solar potential. Raster maps of global radiation of a spatial resolution of $0.5 \mathrm{~m}$ were used in the analysis.

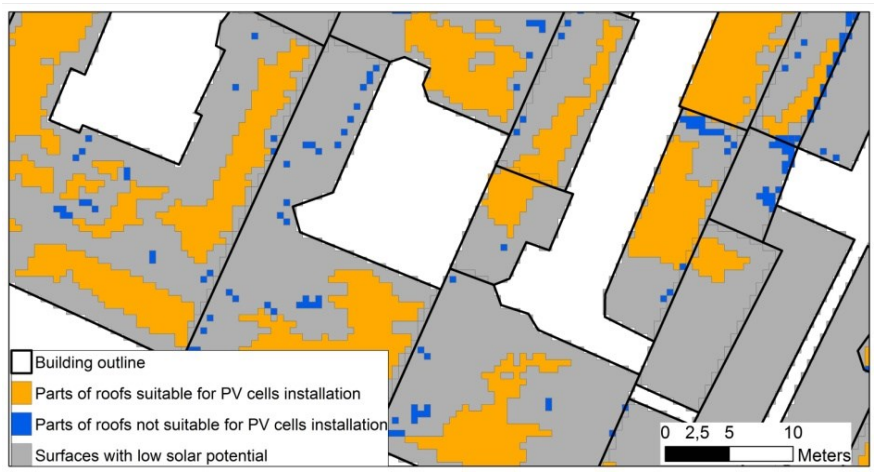

Fig. 4. Pieces of roofs classified as suitable for the installation of photovoltaic cells.

Such selected surfaces were then compared with the total surface of the roofs. As a result, a so-called roof utilization rate (RUR) was obtained as a number between 0 and 1 . Table 2 presents the results of calculations for three analyzed areas of the city centre.

Table 2. Solar potential for roof fragments of buildings, with a potential above $800 \mathrm{kWh} / \mathrm{m}^{2}$ and with the required size and shape.

\begin{tabular}{|c|c|c|c|}
\hline Factor & Part C1 & Part C2 & Part C3 \\
\hline$\%$ number of roofs with areas suitable for FV installations & $47 \%$ & $46 \%$ & $49 \%$ \\
\hline Area of all pieces on these roofs $\left[\mathrm{m}^{2}\right]$ & 41605 & 36817 & 20482 \\
\hline Average area of useful roof pieces $\left[\mathrm{m}^{2}\right]$ & 95.64 & 78.84 & 83.26 \\
\hline $\begin{array}{l}\text { Roof utilization rate (RUR) for all roof pieces of a potential } \\
\geq 800 \mathrm{kWh} / \mathrm{m}^{2}\end{array}$ & 0.42 & 0.44 & 0.36 \\
\hline Average number of pieces on the roof & 1.70 & 1.53 & 1.70 \\
\hline$\%$ share of roofs with a RUR above 0.5 & $37 \%$ & $43 \%$ & $23 \%$ \\
\hline$\%$ share of roofs with a RUR above 0.5 in all roofs of the study area & $17 \%$ & $20 \%$ & $11 \%$ \\
\hline $\begin{array}{l}\text { Total radiation on pieces of a potential } \geq 800 \mathrm{kWh} / \mathrm{m}^{2} \text { and required } \\
\text { size and shape }[\mathrm{GWh}]\end{array}$ & 36.2 & 32.5 & 18.2 \\
\hline
\end{tabular}


Data presented in Table 2 shows that in all the analyzed areas of the city centre about half of the buildings have roofs with surfaces suitable for the installation of solar modules, and the average area of these fragments ranges from 83.26 to $95.64 \mathrm{~m}^{2}$.

For roofs meeting the above-mentioned criteria for installing solar modules, the average coverage rate for panels with a potential above $800 \mathrm{kWh} / \mathrm{m}^{2}$ is in the range from 0.36 to 0.44 , which gives the sum of radiation for all analyzed areas in the range from 18.2 to 36.2 GWh per year.

The results presented in Table 2 also show that among all buildings in the studied areas, only from 11 to $20 \%$ have roofs, on which more than $50 \%$ of the surface is suitable for the installation of solar modules.

\subsection{Coverage of energy demand}

In the conducted analyses, the demand for electricity was specified only for buildings with a residential function, based on annual consumption by 1 person living in the flat. The data for the calculation was adopted in accordance with statistical data published by the Polish Central Statistics Office in 2017 [19]. All calculations were carried out for two variants of average energy consumption, differentiating the use of electricity for space heating. The following was adopted:

- $776.6 \mathrm{kWh} /$ person - for all households and

- $1503.0 \mathrm{kWh} /$ person - for households using only electric energy for space heating.

Based on the number of inhabitants and unit consumption, for each building, the annual electricity demand was calculated and then summed up for the three analyzed areas of the city centre. The results are shown in Table 3.

Table 3. Coverage of electricity demand for residential buildings on the basis of average consumption per capita.

\begin{tabular}{|c|c|c|c|}
\hline Factor & Part C1 & Part C2 & Part C3 \\
\hline \multicolumn{4}{|c|}{ Characteristics of residential buildings } \\
\hline Number of residential buildings & 160 & 261 & 76 \\
\hline Number of inhabitants in the studied area & 4143 & 7000 & 1142 \\
\hline Total usable area of buildings $\left[\mathrm{m}^{2}\right]$ & 147438 & 169484 & 48623 \\
\hline \multicolumn{4}{|c|}{ Annual demand for electricity } \\
\hline For all households ${ }^{*}[\mathrm{kWh}]$ & 3217454 & 5436200 & 886877 \\
\hline For households using electricity for space heating ${ }^{* *}[\mathrm{kWh}]$ & 6226929 & 10521000 & 1716426 \\
\hline \multicolumn{4}{|c|}{$\begin{array}{l}\text { Annual electricity production from installed FV modules } \\
\text { (assumed: efficiency of FV modules }=15 \% \text {, efficiency of the inventor }=87 \% \text { ) }\end{array}$} \\
\hline Average annual production from one roof $[\mathrm{kWh}]$ & 15124 & 11757 & 9835 \\
\hline Production from all useful areas $[\mathrm{kWh}]$ & 2419777 & 3068550 & 747433 \\
\hline \multicolumn{4}{|c|}{ Coverage of demand in \% } \\
\hline All households & $75 \%$ & $56 \%$ & $84 \%$ \\
\hline Households using electricity for space heating & $39 \%$ & $29 \%$ & $44 \%$ \\
\hline
\end{tabular}

In order to determine the amount of energy that can be produced by photovoltaic modules installed on buildings, according to the parameters specified by the manufacturers and based on numerous publications [20-23] describing the results of FV systems efficiency tests, the FV module efficiency of $15 \%$ and the efficiency of the inverter used for conversion of electricity from direct current to alternating current equal to $87 \%$ have been established. The $1 \%$ power loss on the electrical wiring was also taken into account. 
By multiplying the amount of solar energy reaching previously selected roof fragments and assumed losses in the FV system, the amount of annual electricity production for each roof in the analyzed areas of the city centre was obtained.

The average annual energy production for one roof is between 10 and $15 \mathrm{MWh}$. Such quantities cover from $56 \%$ to $84 \%$ of the demand of all households in the studied areas. In the case of households that use electricity as the only source of space heating, these values range from $29 \%$ to $44 \%$ of demand.

An additional parameter characterizing the coverage of electricity demand in the analyzed areas of the city centre is the inclusion of calculation results for each residential building located there. Table 4 presents the percentage share of buildings due to the degree of meeting energy demand by installing photovoltaic systems on their roofs.

Table 4. Share of buildings according to the degree of covering the demand for electricity by FV systems.

\begin{tabular}{|c|c|c|c|c|}
\hline & \multicolumn{4}{|c|}{ Percentage of buildings } \\
\hline $\begin{array}{c}\text { Degree of covering the demand for } \\
\text { electricity by the building }\end{array}$ & Part C1 & Part C2 & Part C3 & Average \\
\hline \multicolumn{4}{|c|}{ For all households } \\
\hline up to 50\% & $31 \%$ & $44 \%$ & $25 \%$ & $33 \%$ \\
\hline from 50 to 75\% & $20 \%$ & $24 \%$ & $12 \%$ & $19 \%$ \\
\hline from 75 to 100\% & $16 \%$ & $17 \%$ & $14 \%$ & $16 \%$ \\
\hline over 100\% & $34 \%$ & $15 \%$ & $49 \%$ & $32 \%$ \\
\hline For households using electricity for space heating \\
\hline up to 50\% & $66 \%$ & $83 \%$ & $50 \%$ & $66 \%$ \\
\hline from 50 to 75\% & $11 \%$ & $11 \%$ & $18 \%$ & $14 \%$ \\
\hline from 75 to $100 \%$ & $7 \%$ & $2 \%$ & $7 \%$ & $5 \%$ \\
\hline over $100 \%$ & $16 \%$ & $4 \%$ & $25 \%$ & $15 \%$ \\
\hline
\end{tabular}

The results presented in Table 4 indicate that approximately $33 \%$ of residential buildings in the analyzed areas will be able to cover up to $50 \%$ of the energy demand from solar modules installed on the roof. If we take into account households using electricity for space heating, as much as $66 \%$ of buildings will be less than half of their demand.

Coverage of energy demand by FV systems will be achieved for about $32 \%$ of buildings, and in the case of residents using electricity for space heating, only $15 \%$ of buildings.

\section{Conclusions}

Urban development has huge energy potential. The amount of energy that can be obtained from photovoltaic systems installed on the roofs of buildings can significantly improve the use of renewable energy sources. However, the analyses carried out showed that to meet the needs of residents of city centres, the amount of energy produced in this way is insufficient. For just about $1 / 3$ of buildings, FV systems installed on roofs will satisfy the basic energy needs of their residents. In the case of using electric heating in households, this amount will be reduced by half - to $1 / 6$ of buildings.

However, the technological progress [24] we are witnessing in the near future may bring a solution to this problem. Currently available photovoltaic modules have an efficiency of 14 to $18 \%$. Increasing the efficiency of these devices will significantly contribute to the increase in the efficiency of using this technology. 
The studies were conducted with instruments provided with financial support as part of the project: 'Implementation of the $2^{\text {nd }}$ Stage of the Regional Innovation Centre' co-financed by the European Regional Development Fund for the Regional Operational Programme for the Kuyavian-Pomeranian Province for the Years 2007-2013.

\section{References}

1. B. L. Stoll, T. A. Smith, M. R. Deinert, Environ. Res. Lett. 8014042 (2013)

2. K. Forinash, Physics and the Environment, (Morgan \& Claypool Publishers 2017)

3. E. Lucchi, G. Garegnani, L. Maturi, D. Moser, Intern. Conf. Energy Efficiency and Historic Buildings, 118 (2014)

4. L. De Boeck, S. Van Asch, P. De Bruecker, A. Audenaert, Renewable Energy 87, 42 (2016)

5. M. Súri, T. Huld, E. D. Dunlop, Int. J. Sust. Energy, 24, 55 (2005).

6. A. Bujarkiewicz, J. Sztubecki, M. Sztubecka, CEER, 28 v.1, 26 (2018)

7. M. Montavon, J.-L. Scartezzini, R. Compagnon, Solar Energy Utilisation Potential of three different Swiss Urban Sites, 503 (2014)

8. E. Caamaño-Martín, E. Higueras Garcia, J. Neila et al., WIT Transactions on Ecology and the Environment 155, 675 (2012)

9. C. Perpiña Castillo, F. Batista e Silva, C. Lavalle, Energy Policy, 88, 86 (2016)

10. G. Franco, A. Magrini, Historical Buildings and Energy (Springer, 2017)A

11. Yearly sum of global irradiation on optimally-inclined surface in Poland, PVGIS, E. C., (http://re.jrc.ec.europa.eu/pvgis/countries/europe/g13yopt_pl.png, acc. 04.04.2018)

12. Energy Regulatory Office in Poland, RES, National RES potential in numbers (http://www.ure.gov.pl/, access 04.09.2017)

13. A. Miazga, D. Owczarek, A cold house, a dark house - energy poverty in Poland, IBS Working Paper 16 (2015)

14. P. Redweik, C. Catita, M. Brito, Solar Energy 97, 332 (2013)

15. M. Mrówczyńska, M. Wawer, JCEEA, XXXII, 62, v.4, 321 (2015)

16. L. Bergamasco, P. Asinari, Solar Energy, 85, i.5, 1041 (2011)

17. G. Agugiaro, F. Nex, F. Remondino, R. De Filippi, S. Droghetti, C. Furlanello, ISPRS Annals of the Photogrammetry, RSSIS, v.I-2, 177 (2012)

18. I. Skrzypczak, W. Kokoszka, D. Zientek, J. Kogut, CEER 24(1), 69 (2017)

19. Polish Central Statistics Office (GUS), Statistical Information and Elaboration, Energy consumption in households in 2015 (2017)

20. P. Gil, Rynek Energii 4,75 (2015)

21. M. Green, K. Emery, Y. Hishikawa, W. Warta, E.D. Dunlop, Prog. Photovolt.: Res. Appl., 22, 1 (2014)

22. O. Schultz, S.W. Glunz, G.P. Willeke, Prog. Photovolt.: Res Appl. 12, 553 (2004)

23. B. Szymański, Instalacje fotowoltaiczne (GLOBEnergia, 2017)

24. M.Yamaguchi, L. Zhu, H. Akiyama et al., Japanese J. App. Phys. 57, 04 FS03 (2018) 